\section{SLEEP AND CHILDHOOD MENTAL HEALTH: ROLE OF PHYSICAL ACTIVITY AND CARDIORESPIRATORY FITNESS}

\author{
SONO ESAÚDE MENTAL INFANTIL:PAPEL DA ATIVIDADEFISICA E APTIDÃO CARDIORRESPIRATÓRIA
}

SUEÑO Y SALUD MENTAL INFANTIL:PAPEL DE LA ACTIVIDAD FÍSICA Y APTITUD CARDIORRESPIRATORIA
Original Article

ARTIGO ORIGINAL Artículo Original
Camila Felin Fochesatto' (ID (Physical Education Professional) Adroaldo Gaya' (DD (Physical Education Professional) Caroline Brand ${ }^{1}$ ID (Physical Education Professional) Jorge Mota² (iD

(Physical Education Professional) Denise Ruschel Bandeira ${ }^{3}$ (DD (Psychologist)

Vanilson Batista Lemes ${ }^{1}$ (D) (Physical Education Professional) Clarice Maria de Lucena Martins ${ }^{4}$ (ID (Physical Education Professional) Anelise Reis Gaya' ${ }^{1}$ (D) (Physical Education Professional)

1. Universidade Federal do Rio Grande do Sul (UFRGS), Escola de Educação Física, Fisioterapia e Dança, Human Movement Sciences Graduate Studies Program, Porto Alegre, RS, Brazil. 2. Universidade do Porto, Faculdade de Desporto, Porto, Portugal.

3. Universidade Federal do Rio Grande do Sul (UFRGS), Instituto de Psicologia, Psychology Graduate Studies Program, Porto Alegre, RS, Brazil.

4. Universidade Federal da Paraíba (UFPB), Physical Activity, Health and Leisure Research Center, João Pessoa, Paraíba, Brazil.

\section{Correspondence:}

Camila Felin Fochesatto.

Rua Felizardo, 750, Jardim Botânico, Porto Alegre, RS, Brazil,

camila-fochesatto@hotmail.com

\begin{abstract}
Introduction: Sleep is considered an important health indicator and plays a key role in brain development and plasticity. Objective: To ascertain whether there is a relationship between sleep quality and mental health indicators and whether organized physical activity (PA) or cardiorespiratory fitness (CRF) act as moderators of this association. Methods: This is a cross-sectional study with a quantitative approach. The sample consisted of 226 students between six and 11 years of age, male and female, in the early years of elementary education at a public school in Porto Alegre, Brazil, which was selected for convenience. CRF was measured by running test and six-minute walk. Sleep quality and organized physical activity outside of school were verified through an anamnesis, socioeconomic status through an adaptation of the ABEP (Brazilian Association of Research Companies) questionnaire, and mental health indicators with the assistance of the Strengths and Difficulties Questionnaire, all answered by parents. Frequencies, means, standard deviations and generalized linear models were used for the data analysis, while a $95 \%$ confidence interval was used for the analyses. Results: Sleep quality was associated with total difficulties ( $\beta=7.659, p<0.001$ ), emotional symptoms $(\beta=1.754 ; p=0.001)$, hyperactivity/inattentiveness $(\beta=3.054, p<0.001)$, conduct problems $(\beta=1.619, p<0.001)$ and peer relationship problems $(\beta=1.231 ; p=0.007)$ in boys. In girls it was related to total difficulties $(\beta=3.421 ; p=0.006)$, and conduct problems ( $\beta=1.235 ; \beta=0.003$ ). However, the interactions were not significant. Conclusion: Although they occur independently, stress is placed on the importance of sleeping well, engaging in organized PA and having good CRF levels for the improvement and maintenance of mental health. Level of evidence III; Case-control study.
\end{abstract}

Keywords: Mental health; Sleep; Physical activity; Cardiorespiratory fitness; Children.

\section{RESUMO}

Introdução: O sono é considerado um importante indicador da saúde e tem papel fundamental no desenvolvimento e na plasticidade cerebral. Objetivo: Verificar se há relação entre a qualidade do sono e os indicadores de saúde mental ese a atividade física (AF) organizada ou aptidão cardiorrespiratória (APCR) atuam como moderadores dessa associação. Métodos: Trata-se de um estudo de corte transversal com abordagem quantitativa. A amostra foi composta por 226 alunos entre seis a 11 anos de idade do sexo feminino e masculino, estudantes dos anos iniciais do ensino fundamental de uma escola pública de Porto Alegre - Brasil, sendo a mesma selecionada por critério de conveniência. A APCR foi mensurada através do teste de corrida e da caminhada de seis minutos. A qualidade do sono e a AF organizada fora da escola foram verificadas através de uma anamnese, o nivel socioeconômico através de uma adaptação do questionário da ABEP (Associação Brasileira de Empresas de Pesquisa) e os indicadores da saúde mental com o auxilio do Strengths and Difficulties Questionnaire, todos respondidos pelos pais. Para a análise de dados, utilizaram-se frequências, médias e desvios padrão e modelos lineares generalizados. Para as análises, utilizou-se um intervalo de confiança de $95 \%$. Resultados: A qualidade do sono apresentou associação com o total de dificuldades ( $\beta=7,659 ; p<0,001)$, sintomas emocionais $(\beta=1,754 ; p=0,001)$, hiperatividade/déficit de atenção ( $\beta=3,054$; $p<0,001)$, problemas de conduta $(\beta=1,619 ; p<0,001)$ e problemas de relacionamento com colegas $(\beta=1,231 ; p=0,007)$, nos meninos. Já nas meninas, apresentou relação com o total de dificuldades $(\beta=3,421 ; p=0,006)$ e problemas de conduta ( $\beta=1,235 ; p=0,003)$. No entanto, as interações não foram significativas. Conclusão: Apesar de ocorrerem por vias independentes, destaca-se a importância de dormir bem, praticar AF organizada e ter bons níveis de APCR para a melhora e manutenção da saúde mental. Nível de evidência III; Estudo caso controle.

Descritores: Saúde mental; Sono; Exercício físico; Aptidão cardiorrespiratória; Crianças.

\section{RESUMEN}

Introducción: El sueño es considerado un indicador importante de la salud y juega un papel fundamental en el desarrollo y la plasticidad cerebral. Objetivo: Verificar si hay relación entre la calidad del sueño y los indicadores de salud mental y si la actividad física (AF) organizada o aptitud cardiorrespiratoria (APCR) actúan como moderadores de esa asociación. Métodos: Se trata de un estudio de corte transversal, con abordaje cuantitativo. La muestra fue compuesta por 226 alumnos entre seis a 11 años de edad del sexo femenino y masculino, estudiantes de los años iniciales de la enseñanza fundamental de una escuela pública de Porto Alegre-Brasil, siendo la misma seleccionada por criterio de conveniencia. La APCR se midió a través del test de carrera y de caminata de seis minutos. La calidad del sueño y la AF organizada fuera de la escuela fueron verificadas a través de una anamnesis, el nivel socioeconómico a través de una 
adaptación del cuestionario de la ABEP (sigla para Asociación Brasileña de Empresas de Encuestas), y los indicadores de salud mental con la ayuda de Strengths and Difficulties Questionnaire, todos respondidos por los padres. Para el análisis de datos, se utilizaron frecuencias, promedios y desviaciones estándary modelos lineales generalizados. Para los análisis, se utilizó un intervalo de confianza de $95 \%$. Resultados: La calidad del sueño presentó asociación con el total de dificultades $(\beta=7,659, p<0,001)$, sintomas emocionales $(\beta=1,754 ; p=0,001)$, hiperactividad/déficit de atención ( $\beta$ $=3,054 ; p<0,001)$ problemas de conducta $(\beta=1,619, p<0,001)$, y problemas de relacionamiento con colegas $(\beta=1,231$; $p=0,007)$ en los niños. En las niñas, presentó relación con el total de dificultades $(\beta=3,421 ; p=0,006)$ y problemas de conducta ( $\beta=1,235 ; p=0,003$ ). Sin embargo, las interacciones no fueron significativas. Conclusión: A pesar de ocurrir por vías independientes, se destaca la importancia de dormir bien, practicar AF organizada y tener buenos niveles de APCR para la mejora y mantenimiento de la salud mental. Nivel de evidencia III; Estudio caso control.

Descriptores: Salud mental; Sueño; Ejercicio físico; Capacidad cardiovascular; Niños.

\section{INTRODUCTION}

Sleep is considered an important health indicator. For efficient sleep, five dimensions must be addressed: sleep duration (total hours of sleep achieved within 24 hours), durability or continuity of sleep (ease falling asleep and going back to sleep), schedule (sleep timing within 24 hours), readiness/drowsiness (ability to maintain a state of alert wakefulness), and satisfaction/quality (subjective sleep assessment). ${ }^{1}$

The prevalence of sleep problems in children is between $25 \%$ and $50 \% .{ }^{2}$ This figure represents grounds for concern as sleep plays a key role in brain development and plasticity. ${ }^{3}$ In addition, children affected by this difficulty often present associations with neurobehavioral disorders and a risk to mental health indicators. ${ }^{4,5}$

Moreover, studies have shown that organized physical activity (PA) and cardiorespiratory fitness (CRF) are also associated with mental health. These relationships are present in total difficulties and emotional symptoms with $\mathrm{PA}^{6,7}$ and total difficulties, hyperactivity/inattentiveness and peer relationship problems with CRF.8-10 It is speculated that these relationships could be explained by physiological, behavioral and social pathways."1

The new Canadian 24-Hour Movement Guidelines for the Early Years (0-4 years) ${ }^{12}$ present a continuous behavior that must be adopted to ensure good health in several aspects, including mental health. In this context, it is proposed that children undertake 60 minutes of moderate/vigorous PA, and have 10 to 13 hours of good quality sleep. Considering that there is a gap in the literature regarding the variables addressed in the present study in this age group, the objective of this research project was to ascertain whether there is a relationship between sleep quality and mental health indicators and whether organized PA or CRF act as moderators of this association. Thus, it was hypothesized that there is a relationship between sleep quality and mental health indicators and that, regardless of sleep quality, organized PA or good levels of CRF would result in lower scores on mental health indicators.

\section{MATERIALS AND METHODS}

A cross-sectional study with a quantitative approach. The sample consisted of 226 students (118 boys) between six and 11 years of age, in the early years of elementary education at a public school in Porto Alegre - Brazil, which was selected for convenience. Parents/guardians signed the Informed Consent Form. This study was approved by the Institutional Review Board (Human Research) of the Universidade Federal do Rio Grande do Sul under opinion number 2.611.180.

The minimum number of subjects in the sample was calculated using $G^{*}$ Power software, version 3.1. A small effect size $\left(f^{2}=0.13\right)$, test power of 0.80 , and an alpha of 0.05 were applied. Linear regression models were worked separately by sex, with five predictors.
We also considered an increase of approximately 10\% to make up for possible losses and refusals, arriving at an approximate number of 100 children of both sexes.

In this context, the sample consisted of 118 boys and 108 girls for the descriptive analyses, while for the moderation analysis regarding PA the sample was made up of 114 boys, and for CRF, 99.

Parents attended a meeting for the collection of data on mental health, sleep quality, and organized PA outside of school. An individual meeting was scheduled at the school for those unable to attend. CRF and anthropometric assessments were conducted at the school by a team of trained researchers.

Sleep quality was verified through a question addressed to the parents. They indicated whether the quality of their child's sleep was "very good", "good", "poor" or "very poor", with results categorized as "good" and "poor" for analysis purposes. For PA, they answered the following question: Does your child engage in organized PA outside of school? The answer options were "yes" and "no".

Mental health was assessed through the Strengths and Difficulties Questionnaire (SDQ), which consists of an epidemiological questionnaire of behavioral screening. It presents three versions to be answered by children, teachers and, in this case, by their parents/guardians. The SDQ addresses behavioral issues in children aged three to 12 years. It contains 25 items subdivided into the following scales: Emotional symptoms; Conduct problems; Hyperactivity/inattentiveness; Peer relationship problems and Prosocial behavior. The parent or guardian was supposed to consider the child's last six months and mark "True,","More or less true," and "False." Scores were then generated for each domain and for total difficulties (sum of domains), being categorized as healthy and clinically significant. The internal consistency (Cronbach's alpha) of the SDQ scales was 0.80 for total difficulties; 0.55 for emotional symptoms; 0.62 for conduct problems; 0.72 for hyperactivity/inattentiveness and 0.47 for peer relationship problems.

Cardiorespiratory fitness was evaluated through the six-minute walk/ run test, according to Proesp-Br $\mathrm{rr}^{13}$ : the students were divided into groups based on the size of the track. The children were instructed to run as long as possible, emphasizing the importance of maintaining a constant running pace. Running times of $3^{\prime}$ and $5^{\prime}$ were announced. At the end of the test the students received a signal to stop running and remain where they were to enable total distance (in meters) to be recorded.

Height and body mass were assessed according to PROESP-Br procedures..$^{13}$ Height was determined using a $1.5 \mathrm{~m}$ measuring tape (Carci, São Paulo) - attached to the wall and extended from the bottom up, with the children standing upright with their feet and trunk against the wall. This measurement was noted down in centimeters to one decimal place. Body mass was measured using anthropometric scales with accuracy of 500 grams (Plenna Wave MEA-07707, São Paulo) and recorded in kilograms using one decimal place. The children were supposed to be 
barefoot, wearing light clothing, and standing with their arms at their sides. The results were then used to calculate body mass index (BMI).

The questionnaire of the Brazilian Association of Research Companies (Associação Brasileira de Empresas de Pesquisa) ${ }^{14}$ was used to verify socioeconomic status, considering the level of education of the head of household and their possession of a number of specified items. The respondents then received a score based on their answers. The sum of these scores indicated the social class in which the family belongs: $A 1$, $A 2, B 1, B 2, C 1, C 2$, D or E. The following categories were then created for social classes: upper $(A 1+A 2)$, middle $(B 1+B 2+C 1+C 2)$ and lower $(D+E)$.

\section{Statistical analysis}

Data were analyzed using descriptive statistics, with mean, standard deviation and frequency. From then on, generalized linear models were used for the following models: association of mental health indicator $x$ sleep quality, association of mental health indicator $x$ organized PA, association of mental health indicator $x$ moderation of organized PA*sleep quality, association of mental health indicator and CRF and association between mental health indicator $x$ moderation of sleep quality ${ }^{*}$ CRF. All the models were adjusted for age and socioeconomic status.

\section{RESULTS}

Table 1 presents the characteristics of the sample in terms of CRF, BMI, age, mental health indicators, sleep quality, SES and PA, separated by sex.

Table 2 presents the associations between mental health indicator $x$ sleep quality, association of mental health indicator $x$ organized PA, association of mental health indicator $x$ moderation of organized PA*sleep quality, association of mental health indicator and CRF and association between the mental health indicator $x$ moderation of sleep quality* ${ }^{*}$ CRF. In the boys, an association was found between all mental health indicators with sleep quality, total difficulties and emotional symptoms with organized PA and total difficulties, hyperactivity/inattentiveness and peer relationship problems with CRF. In the girls, however, an association was observed between total difficulties and conduct problems with sleep quality. There was no moderation in any of the models.

Table 1. Description of the sample characteristics, separated by sex.

\begin{tabular}{|c|c|c|c|c|}
\hline \multirow[t]{2}{*}{ Sample characteristics } & \multicolumn{2}{|r|}{$\begin{array}{c}\text { Boys } \\
118(52.2 \%)\end{array}$} & \multicolumn{2}{|r|}{$\begin{array}{c}\text { Girls } \\
108(47.8 \%)\end{array}$} \\
\hline & $\mathbf{N}$ & Mean (SD) & $\mathbf{N}$ & Mean (SD) \\
\hline $\mathrm{CRF}(\mathrm{m})$ & 102 & $791.37(138.07)$ & 100 & $749.75(109.46)$ \\
\hline $\mathrm{BMI}\left(\mathrm{kg} / \mathrm{m}^{2}\right)$ & 112 & $17.93(3.51)$ & 108 & $17.96(4.10)$ \\
\hline Age (years) & 118 & $8.42(1.45)$ & 107 & $8.44(1.53)$ \\
\hline \multicolumn{2}{|r|}{$\mathbf{N}$} & $\%$ & $\mathbf{N}$ & $\%$ \\
\hline \multicolumn{5}{|l|}{ Total difficulties } \\
\hline Healthy & 92 & 78.0 & 87 & 81.3 \\
\hline Clinically significant & 26 & 22.0 & 20 & 18.7 \\
\hline \multicolumn{5}{|l|}{ Emotional symptoms } \\
\hline Healthy & 82 & 69.5 & 78 & 72.2 \\
\hline Clinically significant & 36 & 30.5 & 29 & 27.1 \\
\hline \multicolumn{5}{|l|}{ Conduct problems } \\
\hline Healthy & 96 & 81.4 & 87 & 81.3 \\
\hline Clinically significant & 22 & 18.6 & 20 & 18.7 \\
\hline \multicolumn{5}{|l|}{ Hyperactivity/inattentiveness } \\
\hline Healthy & 93 & 78.8 & 86 & 80.4 \\
\hline Clinically significant & 25 & 21.2 & 21 & 19.6 \\
\hline \multicolumn{5}{|l|}{ Peer relationship problems } \\
\hline Healthy & 94 & 79.7 & 91 & 85.0 \\
\hline Clinically significant & 24 & 20.3 & 16 & 15.0 \\
\hline \multicolumn{5}{|l|}{ Sleep quality } \\
\hline Good & 93 & 80.9 & 83 & 78.3 \\
\hline Poor & 22 & 19.1 & 23 & 21.7 \\
\hline \multicolumn{5}{|l|}{ SES } \\
\hline Middle & 37 & 32.5 & 32 & 31.4 \\
\hline Lower & 77 & 67.5 & 70 & 68.6 \\
\hline \multicolumn{5}{|l|}{ PA organized outside school } \\
\hline Yes & 57 & 49.6 & 41 & 39.0 \\
\hline No & 58 & 50.4 & 64 & 61.0 \\
\hline
\end{tabular}

\section{DISCUSSION}

The main findings of this study are frequency of $18.6 \%$ in boys and $21.3 \%$ in girls who sleep poorly. In addition, sleep quality was associated with total difficulties, emotional symptoms, hyperactivity/inattentiveness, conduct problems, and peer relationship problems in the boys. In girls, sleep quality was related to total difficulties and conduct problems. Furthermore, organized PA outside of school and CRF do not act as moderators in the relationship between sleep quality and mental health indicators.

It is possible to note that about $20 \%$ of the children had poor sleep quality. The literature, in turn, shows an incidence between 25\% and 45\% of the healthy child population, with difficulties falling and staying asleep. ${ }^{15}$ These data give grounds for concern as this behavior has been associated with several parameters of general health, including mental health. ${ }^{16}$

From a more specific perspective of the different dimensions of mental health addressed in this study, it was noted that sleep quality in boys and girls had an inverse association with total difficulties, i.e., the sum of all the indicators. These findings may be related to the statements observed in the literature about the role of sleep quality in brain activity - an indispensable process for balanced cognitive and emotional functioning. Accordingly, studies have reinforced the association of sleep quality with psychiatric disorders (internalizing and externalizing behavior problems) and cognitive difficulties. The brain substrates affected by sleep problems are the amygdala, prefrontal cortex, and basal ganglia, and therefore emotional issues, executive functions, and reward anticipation are compromised. ${ }^{15}$

In fact, one of the aspects presented as high-risk behavior for anxiety and depression is sleep problems. ${ }^{17}$ This study pinpoints an association between sleep quality and emotional symptoms in boys. The literature corroborates our findings, indicating that children between six and 11 years of age who sleep poorly suffer negative impacts on emotional symptoms, and suggests that caregivers do not recognize poor sleep quality as an issue. ${ }^{18}$

In addition, results similar to ours show that the characteristics of childhood sleep seem to be able to predict behavioral and emotional problems in adolescence. ${ }^{19}$ This is owing to the fact that depressed or anxious individuals have excessive amygdala reactivity, and sleep problems have been shown to stimulate this area of the brain to a large extent. ${ }^{20}$

Sleep quality was also associated with conduct problems in boys and girls. Such evidence was also found in a study carried out with adolescents, indicating that those who had sleep problems were more likely to develop conduct problems both immediately and one year later. ${ }^{21}$ Furthermore, a relationship was found in children between the number of times sleep is interrupted at night (which compromises its quality) and conduct problems. ${ }^{4}$ On the other hand, a child who has one hour less sleep on average may be at risk for conduct problems. ${ }^{22}$

In hyperactivity/inattentiveness, a relationship was found with sleep quality in boys. Corroborating our findings, a longitudinal study showed that early childhood sleep problems indicate subsequent attention problems that may persevere through adolescence. ${ }^{23}$ When we consider the comorbidities of this indicator, anxious children with hyperactivity/ inattentiveness presented higher scores of sleep problems compared to those with hyperactivity/inattentiveness alone. ${ }^{24}$ Furthermore, according to researchers, $70 \%$ of children with abnormal hyperactivity/ inattentiveness indicators have sleep problems. ${ }^{5}$

In view of the above, and since the World Health Organization defined sleep and PA as components of a basic triad for the promotion of mental health in 2005, ${ }^{25}$ and given the gaps in the literature, it was suggested that organized PA and CRF could moderate the relationship between sleep quality and mental health indicators.

Assuming that organized PA and CRF could improve sleep quality, ${ }^{26}$ it was hypothesized that, regardless of the child's sleep quality, if they undertook PA or were able to do so, they would have lower scores 
Table 2. Association between sleep quality, PA, SES and age with the mental health indicator.

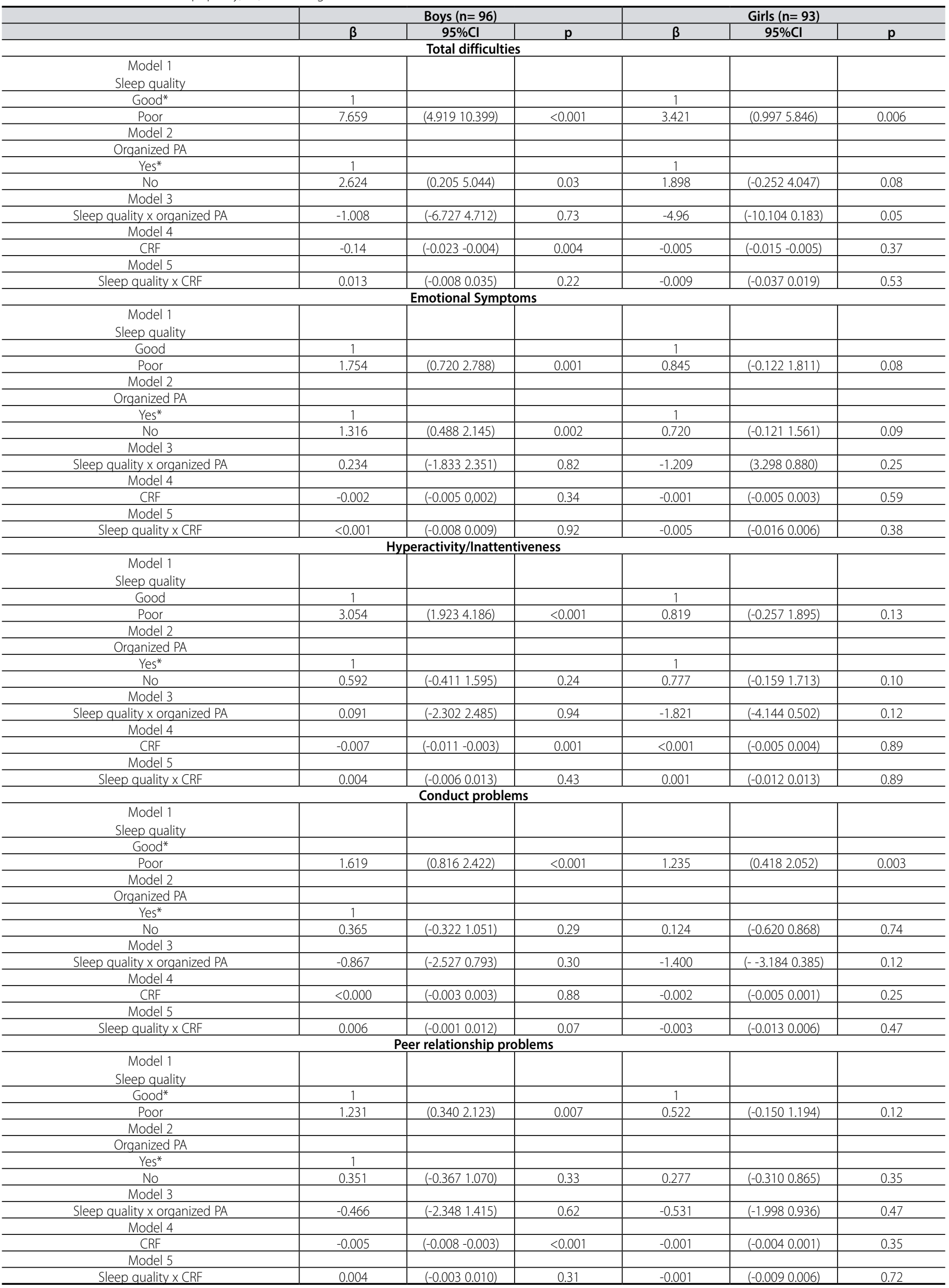


on mental health indicators. However, organized PA and CRF did not moderate the relationship between sleep quality and mental health indicators. Possibly because sleep quality, organized PA, and CRF are associated with mental health indicators in different ways, regardless of their correlations. According to the above, sleep quality interferes with the child's behavioral and physiological issues. ${ }^{15,27}$ Likewise, the variables associated with PA may also play a physiological/behavioral and social role through group activities, such as in sports. ${ }^{11}$

Corroborating this study, a survey of Chinese youths investigated the grouping of some risk factors, including physical inactivity and sleep problems, into mental health indicators. The results show that the risks of anxiety and depression were higher in those who reported poor sleep, having no association with PA. ${ }^{28}$ On the other hand, in a similar survey, young people from 23 countries in the Americas who fulfilled PA recommendations reported better well-being and lower risk of depression, with no association between sleep and mental health. ${ }^{29}$ Moreover, a survey conducted with Swiss youths sought to analyze whether the association between subjective sleep complaints and depression was moderated by moderate/vigorous PA. Although the moderation was not significant, the means showed higher scores for depression both in those who do not fulfill PA recommendations and in those who report sleep problems. ${ }^{30}$

The main strengths of this study are the new information regarding the relationship between mental health and sleep quality. In addition, as far as we known, this is one of the first studies to cover moderation with PA and CRF in the relationship between sleep quality and mental health in children. We must emphasize the relevance of investigating this topic further, as it is increasingly evident that relationships, such as that of sleep quality with mental health, may be influenced by other variables that must be considered, as is the case of PA or CRF. Nevertheless, limitations should be considered. This is a study in which sleep quality, mental health and PA were measured indirectly, which may not represent behaviors. In addition, the sample was selected due to its convenience, which may not represent the general population.

\section{CONCLUSION}

The sleep quality was associated with the indicators total difficulties and conduct problems in both sexes, as well as emotional symptoms, hyperactivity/inattentiveness and peer relationship problems in boys. However, organized PA and CRF were not moderators of the association between sleep quality and mental health. Although they occur independently, we must stress the importance of sleeping well, undertaking organized PA and having good CRF levels to improve and maintain mental health.

\section{ACKNOWLEDGMENTS}

The Coordenação de Aperfeiçoamento de Pessoal de Nível Superior (CAPES, the Brazilian federal agency for support and evaluation of graduate education) and the financial aid provided by the Conselho Nacional de Desenvolvimento Científico e Tecnológico (CNPq, National Council for Scientific and Technological Development) under number 401969/2016-9.

All authors declare no potential conflict of interest related to this article

AUTHORS' CONTRIBUTIONS: Each author made significant individual contributions to this manuscript. CFF (0000-0002-8777-074X)*: conception of the work, data collection, data processing and writing of the work; AG (0000-0002-5941-5089)*: methodological conception and final review; CB (0000-0002-5624-3592)*: statistical analysis, writing of the work; JM (0000-0001-7571-9181)*: writing and final review of the work; DRB (0000-0001-9867-2718)*: conception of the work and intellectual concept; VBL (0000-0003-3298-4449)*: collection processing and interpretation of data; CMLM (0000-0002-4947-9329)*: writing and revision of the work; ARG (0000-0002-8335-6947)*: conception of the work, statistical analysis and final review. All authors participated and approved the final version of the manuscript. *ORCID (Open Researcher and Contributor ID).

\section{REFERENCES}

1. Buysse DJ. Sleep health: can we define it? Does it matter? Sleep. 2014;37(1):9-17.

2. Bhargava S. Diagnosis and management of common sleep problems in children. Pediatr Rev. 2011;32(3):91-9.

3. Saré RM, Levine M, Hildreth C, Picchioni D, Smith CB. Chronic sleep restriction during development can lead to long- lasting behavioral effects. Physiol Behav. 2016;155:208-17.

4. Reynaud E, Forhan A, Heude B, Charles MA, Plancoulaine S; EDEN-Mother-Child Cohort Study Group. Night-waking and behavior in preschoolers: a developmental trajectory approach. Sleep Med. 2018;43:90-5

5. Lycett $\mathrm{K}$, Sciberras $\mathrm{E}$, Hiscock $\mathrm{H}$, Mensah FK. Sleep problem trajectories and well-being in children with attention-deficit hyperactivity disorder: a prospective cohort study. J Dev Behav Pediatr. 2016;37(5):405-14

6. Sagatun A, Søgaard AJ, Bjertness E, Selmer R, Heyerdahl S. The association between weekly hours of physical activity and mental health: A three-year follow-up study of 15-16-year-old students in the city of Oslo, Norway. BMC Public Health. 2007;7:155.

7. Ortlieb S, Schneider G, Koletzko S, Berdel D, von Berg A, Bauer C-P, et al. Physical activity and its correlates in children: a cross-sectional study (the GINIplus \& LISAplus studies). BMC Public Health. 2013;13:349.

8. Shomaker LB, Tanofsky-Kraff M, Zocca JM, Field SE, Drinkard B, Yanovski JA. Depressive symptoms and cardiorespiratory fitness in obese adolescents. J Adolesc Health. 2012;50(1):87-92.

9. Gapin JI, Labban JD, Etnier JL. The effects of physical activity on attention deficit hyperactivity disorder symptoms: The evidence. Prev Med. 2011;52(Suppl 1):S70-4.

10. Smith AL, Ullrich-French S, Walker II E, Hurley KS. Peer relationship profiles and motivation in youth sport. J Sport Exerc Psychol. 2006;28(3):362-82

11. Lubans D, Richards J, Hillman C, Faulkner G, Beauchamp M, Nilsson M, et al. Physical activity for cognitive and mental health in youth : a systematic review of mechanisms. 2016;138(3). pii:e20161642.

12. Tremblay MS, Carson V, Chaput JP, Gorber SC, Dinh I, Katzmarzyk PT, et al. Canadian 24-hour movement guidelines for children and youth: an integration of physical activity, sedentary behaviour, and sleep. Appl Physiol Nutr Metab. 2016;41(6 Suppl 3):S311-27.

13. Gaya A, Gaya A. Projeto Esporte Brasil PROESP-Br Manual de testes e avaliação. Porto Alegre: Perfil, 2016.

14. Ambrósio B, Wakaguri T, Ibope K. Critério Brasil 2015 e atualização da distribuição de classes para 2016. ABEP. 2016;1-6.

15. Maski KP, Kothare SV. Sleep deprivation and neurobehavioral functioning in children. Int J Psychophysiol. 2013;89(2):259-64.
16. Duggan KA, Reynolds CA, Kern ML, Friedman HS. Childhood sleep duration and lifelong mortality risk. HHS Public Access. 2014;33(10):1195-203.

17. Stubbs B, Rosenbaum S, Vancampfort D, Ward PB, Schuch FB. Exercise improves cardiorespiratory fitness in people with depression: a meta-analysis of randomized control trials. J Affect Disord. 2016;190:249-53.

18. Van Dyk TR, Thompson RW, Nelson TD. Daily bidirectional relationships between sleep and mental he alth symptoms in youth with emotional and behavioral problems. J Pediatr Psychol. 2016;41(9):983-92.

19. Gregory AM, O'Connor TG. Sleep problems in childhood: a longitudinal study of developmental change and association with behavioral problems. J Am Acad Child Adolesc Psychiatry. 2002;41(8):964-71.

20. Klumpp H, Hosseini B, Phan KL. Self-Reported sleep quality modulates amygdala resting-state functional connectivity in anxiety and depression. Front Psychiatry. 2018;9:220.

21. Lin WH, Yi CC. Unhealthy sleep practices, conduct problems, and daytime functioning during adolescence. J Youth Adolesc. 2015;44(2):431-46.

22. Holley S, Hill CM, Stevenson J. An hour less sleep is a risk factor for childhood conduct problems. Child Care Health Dev. 2011;37(4):563-70.

23. O'Callaghan FV., Al Mamun A, O'Callaghan M, Clavarino A, Williams GM, Bor W, et al. The link between sleep problems in infancy and early childhood and attention problems at 5 and 14 years: Evidence from a birth cohort study. Early Hum Dev. 2010;86(7):419-24.

24. Accardo JA, Marcus CL, Leonard MB, Shults J, Meltzer LJ, Elia J. Associations between psychiatric comorbidities and sleep disturbances in children with attention-deficit/hyperactivity disorder. J Dev Behav Pediatr. 2012;33(2):97-105

25. World Health Organization. Promoting Mental Health. Geneva: World Health Organization, 2004

26. Brand S, Gerber M, Beck J, Hatzinger M, Pühse U, Holsboer-Trachsler E. High exercise levels are related to favorable sleep patterns and psychological functioning in adolescents: a comparison of athletes and controls. J Adolesc Health. 2010;46(2):133-41.

27. Astill RG, Van der Heijden KB, Van IJzendoorn MH, Van Someren EJ. Sleep, cognition, and behavioral problems in school-age children: A century of research meta-analyzed. Psychol Bull. 2012;138(6):1109-38

28. Feng Q, Zhang QL, Du Y, Ye YL, He QQ. Associations of Physical Activity, screen time with depression, anxiety and sleep quality among chinese college freshmen. PLoS One. 2014;9(6):e100914.

29. Pengpid S, Peltzer K. Vigorous physical activity, perceived stress, sleep and mental health among university students from 23 low- and middle-income countries. Int J Adolesc Med Health. 2018.

30. Gerber M, Brand S, Herrmann C, Colledge F, Holsboer-Trachsler E, Pühse U. Increased objectively assessed vigorous-intensity exercise is associated with reduced stress, increased mental health and good objective and subjective sleep in young adults. Physiol Behav. 2014;135:17-24. 